\title{
PENGARUH KEMANDIRIAN BELAJAR DAN LINGKUNGAN BELAJAR SISWA TERHADAP PRESTASI BELAJAR AKUNTANSI SISWA KELAS XI IPS SMA NEGERI 1 SEWON BANTUL TAHUN AJARAN 2010/2011
}

Oleh:

\author{
Pratistya Nor Aini ${ }^{1}$
}

Abdullah Taman ${ }^{2}$

\begin{abstract}
Abstrak
Penelitian ini bertujuan untuk mengetahui: (1) pengaruh Kemandirian Belajar terhadap Prestasi belajar Akuntansi Siswa Kelas XI IPS SMA Negeri 1 Sewon Bantul Tahun Ajaran 2010/2011, (2) pengaruh Lingkungan Belajar Siswa terhadap Prestasi Belajar Akuntansi Siswa Kelas XI IPS SMA Negeri 1 Sewon Bantul Tahun Ajaran 2010/2011, (3) pengaruh Kemandirian Belajar dan Lingkungan Belajar Siswa secara bersama-sama terhadap Prestasi Belajar Akuntansi Siswa Kelas XI IPS SMA Negeri 1 Sewon Bantul Tahun Ajaran 2010/2011.

Penelitian ini merupakan penelitian expost-facto dan penelitian sampel karena sebagian atau wakil populasi yang diteliti sebagai subyek penelitian yaitu siswa kelas XI IPS SMA Negeri 1 Sewon Bantul Tahun Ajaran 2010/2011 yang berjumlah 85 . Pengumpulan data dengan metode kuesioner atau angket dan metode dokumentasi. Metode kuesioner atau angket untuk mengumpulkan data Kemandirian Belajar dan Lingkungan Belajar Siswa sedangkan metode dokumentasi untuk mengetahui nilai Prestasi Belajar Akuntansi. Uji coba instrumen penelitian dilakukan terhadap 30 siswa di SMA Negeri 1 Sewon Bantul. Uji validitas instrumen dengan teknik analisis product moment, sedangkan uji reliabilitas dengan koefisien alpha. Analisis regresi sederhana digunakan untuk mengetahui mengetahui pengaruh Kemandirian Belajar dan Lingkungan Belajar Siswa secara sendiri-sendiri dengan Prestasi Belajar Akuntansi, sedangkan untuk mengetahui pengaruh kedua variabel bebas secara bersama-sama dengan variabel terikat digunakan analisis regresi ganda dua prediktor. Sebelum menganalisis data, terlebih dahulu digunakan pengujian prasyarat analisis meliputi uji linearitas, uji multikolinearitas dan uji normalitas.

Hasil penelitian menunjukkan bahwa: (1) terdapat pengaruh positif dan signifikan Kemandirian Belajar terhadap Prestasi Belajar Akuntansi, dibuktikan $r_{x 1 y}=0.359, r_{x 1 y}^{2}=$ 0,129 , thitung $=3.509$ lebih besar dari $t_{\text {tabel }}=1,98$; (2) terdapat pengaruh positif dan signifikan Lingkungan Belajar Siswa terhadap Prestasi Belajar Akuntansi, dibuktikan dibuktikan $r_{x 2 y}=0.377, r_{x 2 y}^{2}=0,142$, $t_{\text {hitung }}=3.711$ lebih besar dari $t_{\text {tabel }}=1,980 ;$; 3 ) terdapat pengaruh positif dan signifikan Kemandirian Belajar dan Lingkungan Belajar
\end{abstract}

\footnotetext{
${ }^{1}$ Alumni Program Studi Pendidikan Akuntansi UNY

${ }^{2}$ Dosen Jurusan Pendidikan Akuntansi UNY
} 
Siswa secara bersama-sama terhadap Prestasi belajar Akuntansi Siswa kelas XI IPS SMA Negeri 1 Sewon Bantul Tahun Ajaran 2010/2011, dibuktikan dengan $R_{y(1,2)}=0.494$, $\mathrm{R}^{2} \mathrm{y(1,2)}=0.244, \mathrm{~F}_{\text {hitung }}=13.264$ lebih besar dari $\mathrm{F}_{\text {tabel }}=3,11$. Dengan demikian keseluruhan hasil analisis ini mendukung hipotesis yang diajukan.

\section{A. Pendahuluan}

\section{Latar Belakang Masalah}

Sumber daya manusia yang berkualitas merupakan salah satu modal penting dalam pembangunan bangsa Indonesia untuk dapat bertahan di tengah-tengah kompleksitas zaman. Salah satu cara untuk meningkatkan kualitas sumber daya manusia adalah melalui pendidikan. Pendidikan merupakan hal yang utama dan terutama di dalam kehidupan era masa sekarang ini. Sejauh kita memandang maka sejauh itulah kita harus melengkapi diri kita dengan pendidikan. Pendidikan menjadi sarana yang penting dalam pengembangan sumber daya manusia. Melalui pendidikan akan dapat dihasilkan sumber daya manusia yang berkualitas dan mampu bersaing. Salah satu tujuan pendidikan adalah menyiapkan peserta didik menjadi anggota masyarakat yang memiliki kemampuan akademik atau professional yang dapat menerapkan dan mengembangkan ilmu pengetahuan.

Berdasarkan UU RI No. 20 tahun 2003 pasal 13 ayat 1 tentang Sistem Pendidikan Nasional, ada 3 jalur pendidikan yang dapat ditempuh untuk dapat mencapai tujuan pendidikan nasional yaitu pendidikan formal, non formal, dan informal yang dapat saling melengkapi dan memperkaya. Salah satu bentuk pendidikan formal adalah pendidikan di sekolah. Pendidikan di sekolah ini diselenggarakan melalui proses belajar mengajar yang berjenjang dan berkesinambungan. Jenjang pendidikan yang termasuk di sekolah ini yaitu pendidikan dasar, pendidikan menengah, pendidikan tinggi.

Pendidikan menengah merupakan lanjutan dari pendidikan dasar. Pendidikan menengah dilaksanakan untuk mengembangkan kemampuan sosialisasi dan kompetensi peserta didik lebih lanjut dalam dunia kerja atau pendidikan tinggi. Bentuk dari pendidikan menengah salah satunya adalah Sekolah Menengah Atas. Sekolah Menengah Atas merupakan sekolah yang didesain untuk mencetak lulusan yang berkualitas dan manusiawi agar dapat bertahan dalam persaingan yang ada. 
Prestasi belajar Akuntansi yang tinggi khususnya di SMA N 1 Sewon Bantul merupakan dambaan semua pihak, baik pribadi siswa, orang tua maupun pihak sekolah. Pada kenyataannya banyak permasalahan yang timbul dan dihadapi oleh setiap individu dalam mencapai prestasi belajar yang tinggi. Permasalahan-permasalahan yang dihadapi oleh setiap individu ini bersifat kompleks, dan berbeda-beda pada setiap individu. Hal ini dikarenakan dalam proses pencapaian prestasi belajarnya tersebut dipengaruhi oleh banyak faktor-faktor. Secara umum, faktor-faktor tersebut dibedakan menjadi dua faktor, yaitu faktor yang berasal dari dalam diri (faktor intern) dan faktor yang berasal dari luar siswa (faktor ekstern). Faktor yang berasal dari dalam diri siswa meliputi: (1) faktor fisiologi misalnya mengalami sakit, cacat tubuh atau perkembangan yang tidak sempurna, dan (2) faktor psikologis misalnya intelegensi, motivasi, persepsi, sikap, bakat, kemandirian, dan lain-lain. Sedangkan faktor yang berasal dari luar diri siswa, seperti kurikulum, kompetensi profesionalisme guru, fasilitas belajar, lingkungan sekolah, lingkungan keluarga, lingkungan belajar (Slameto, 2010: 54-60).

Apabila faktor-faktor tersebut dimaksimalkan fungsinya maka akan dapat meningkatkan prestasi belajar Akuntansi di SMA N 1 Sewon Bantul. Berdasarkan observasi yang dilakukan oleh peneliti tahun 2011 belum seluruh siswa mencapai Kriteria Ketuntasan Minimum (KKM) pada mata pelajaran Akuntansi. Kriteria Ketuntasan Minimum untuk mata pelajaran Akuntansi di SMA N 1 Sewon Bantul adalah 75. Hal ini dapat dilihat dari setiap nilai ulangan yang diperoleh siswa masih dijumpai nilai di bawah Kriteria Ketuntasan Minimum. Berdasarkan hasil observasi dapat dilihat pada hasil nilai ulangan semester genap mata pelajaran Akuntansi, dimana sebanyak 25\% dari semua siswa kelas XI IPS mendapat nilai dibawah ketuntasan minimal 75 sehingga prestasi belajar yang dicapai siswa SMA N 1 Sewon Bantul belum sepenuhnya optimal.

Pencapaian prestasi belajar Akuntansi yang optimal dalam proses belajar siswa dapat dipengaruhi oleh banyak faktor. Hal inilah yang mungkin menjadi penyebab kurangnya daya serap siswa dalam mencapai prestasi belajar. Dalam proses pembelajaran diperlukan adanya kemandirian belajar agar tercapai tujuan pembelajaran yang baik. 
Kemandirian belajar diartikan sebagai sifat serta kemampuan yang dimiliki siswa untuk melakukan kegiatan belajar aktif, yang didorong oleh motif untuk menguasai sesuatu kompetensi, dan dibangun dengan bekal pengetahuan atau kompetensi yang telah dimiliki. Menurut Haris Mujiman (2007: 1) "Kemandirian Belajar dapat diartikan sebagai sifat serta kemampuan yang dimiliki siswa untuk melakukan kegiatan belajar aktif, yang didorong oleh motif untuk menguasai sesuatu kompetensi yang telah dimiliki”. Seorang siswa dikatakan mempunyai Kemandirian Belajar apabila mempunyai kemauan sendiri untuk belajar akuntansi, siswa mampu memecahkan masalah dalam proses belajar akuntansi, siswa mempunyai tanggung jawab dalam proses belajar akuntansi, dan siswa mempunyai rasa percaya diri dalam setiap proses belajar akuntansi. Pada umumnya siswa tidak mandiri dalam belajar akuntansi terlihat saat siswa mengerjakan ulangan masih terdapat siswa yang kurang percaya diri dengan kemampuannya sendiri.

Kemandirian Belajar dapat terlihat pada kebiasaan-kebiasaan belajar siswa sehari-hari seperti cara siswa merencanakan dan melakukan belajar. Kemandirian Belajar yang tinggi dari siswa sangat diperlukan dalam peningkatan Prestasi Belajar Akuntansi karena akan berpengaruh terhadap terciptanya semangat diri untuk belajar.

Di SMA N 1 Sewon Bantul masih terdapat siswa yang kurang memiliki kemandirian belajar ditandai dengan tidak mengerjakan tugas dan kurang memperhatikan guru pada saat kegiatan belajar mengajar berlangsung seperti melamun dan mengobrol dengan teman. Jadi, siswa belum menerapkan strategi belajar yang rutin, efektif, dan teratur.

Faktor lain yang sangat mempengaruhi tinggi rendahnya hasil belajar siswa adalah lingkungan belajar. Menurut Slameto (2010: 60) lingkungan dibedakan menjadi lingkungan keluarga, sekolah, masyarakat dan semuanya dapat mempengaruhi siswa dalam belajar. Lingkungan belajar siswa meliputi lingkungan fisik terdiri dari tempat belajar, alat-alat belajar belajar akuntansi, sumber belajar akuntansi, penerangan, dan keadaan cuaca. Kondisi lingkungan belajar ini sangat menentukan kelancaran proses pembelajaran misalnya kondisi fisik, lingkungan sosial budaya atau masyarakat, dan lingkungan sekolah. Jika kondisi lingkungan belajar sangat mendukung, maka siswa pun akan lebih bersemangat dalam proses pembelajaran. Misalnya suasana aman dan nyaman sehingga siswa mampu meresapi apa 
yang diajarkan oleh gurunya dan sebaliknya jika kondisi lingkungan kurang mendukung dalam proses pembelajaran, maka siswa akan merasa tidak nyaman dalam hal tersebut berdampak pada motivasi siswa. Kondisi ini mengakibatkan siswa hanya sekedar berangkat sekolah untuk mendengarkan materi yang diajarkan oleh guru tanpa memahami ilmu yang diberikan sehingga menimbulkan prestasi belajar siswa yang rendah.

Lingkungan sekolah SMA Negeri 1 Sewon yang letaknya sangat dekat dengan jalan raya menyebabkan proses kegiatan belajar mengajar agak terganggu. Maka dalam hal ini dapat disimpulkan bahwa lingkungan belajar siswa mempunyai peranan yang sangat penting dalam proses kegiatan belajar siswa yang selanjutnya akan berpengaruh pada pencapaian prestasi belajar akuntansi pada siswa di sekolah.

Berdasarkan uraian di atas, peneliti tertarik untuk melakukan penelitian tentang "Pengaruh Kemandirian Belajar dan Lingkungan Belajar Siswa Terhadap Prestasi Belajar Akuntansi Siswa Kelas XI IPS SMA Negeri I Sewon Bantul Tahun Ajaran 2010/2011”.

\section{Rumusan Masalah}

1. Bagaimanakah pengaruh Kemandirian Belajar terhadap Prestasi Belajar Akuntansi siswa kelas XI IPS SMA Negeri I Sewon Bantul Tahun Ajaran 2010/2011?

2. Bagaimanakah pengaruh Lingkungan Belajar Siswa terhadap Prestasi Belajar Akuntansi siswa kelas XI IPS SMA Negeri I Sewon Bantul Tahun Ajaran 2010/2011?

3. Bagaimanakah pengaruh Kemandirian Belajar dan Lingkungan Belajar Siswa secara bersama-sama terhadap Prestasi Belajar Akuntansi siswa kelas XI IPS Negeri 1 Sewon Bantul Tahun Ajaran 2010/2011?

\section{Kajian Teori}

a. Tinjauan tentang Prestasi Belajar Akuntansi

1) Pengertian Prestasi Belajar Akuntansi

Suharsimi Arikunto (2006: 276) menyebutkan bahwa "Prestasi harus mencerminkan tingkatan-tingkatan siswa sejauh mana telah dapat mencapai tujuan yang ditetapkan setiap 
bidang studi. Simbol yang digunakan untuk menyatakan nilai, baik huruf maupun angka, hendaknya merupakan gambaran tentang prestasi saja".

Sedangkan Nana Syaodih Sukmadinata (2003: 102) mengemukakan bahwa,

Prestasi atau hasil belajar (achievement) merupakan realisasi atau pemekaran dari kecakapan-kecakapan potensial atau kapasitas yang dimiliki seseorang. Penguasaan hasil belajar oleh seseorang dapat dilihat dari perilakunya, baik perilaku dalam bentuk penguasaan pengetahuan, keterampilan berpikir maupun keterampilan motorik. Di sekolah, hasil belajar ini dapat dilihat dari penguasaan siswa akan mata pelajaran yang ditempuhnya.

Menurut Muhibbin Syah (2008: 144-145), "Prestasi Belajar merupakan tingkat keberhasilan siswa dalam mencapai tujuan yang telah ditetapkan dalam sebuah program".

Berdasarkan Hendri Somantri (2007: 19) "Akuntansi adalah seni pencatatan, penggolongan, pengikhtisaran, dan pelaporan transaksi keuangan perusahaan yang terjadi dalam suatu periode tertentu".

Menurut AAA (American Accounting Association) dalam Hendi Somantri (2007: 17) "Akuntansi adalah proses pengidentifikasian, mengukur, dan melaporkan informasi ekonomi untuk memungkinkan adanya penilaian dan pengambilan keputusan yang jelas dan tegas bagi mereka yang menggunakan informasi tersebut".

Dari beberapa uraian di atas dapat disimpulkan bahwa Prestasi Belajar Akuntansi adalah hasil usaha siswa dalam mempelajari materi Akuntansi di sekolah dalam menguasai pengetahuan, sikap, dan keterampilan baik mempelajari, memahami, dan mampu mengerjakan atau menjawab pertanyaan-pertanyaan dalam materi Akuntansi selama periode tertentu yang dinyatakan dengan nilai dalam bentuk angka atau skor yang diperoleh setelah diadakan evaluasi.

\section{b. Tinjauan tentang Kemandirian Belajar}

\section{1) Pengertian Kemandirian Belajar}

Kemandirian belajar siswa diperlukan agar mereka mempunyai tanggung jawab dalam mengatur dan mendisiplinkan dirinya, selain itu dalam mengembangkan kemampuan belajar atau kemauan sendiri. Sikap-sikap tersebut perlu dimiliki oleh siswa sebagai peserta didik karena hal tersebut merupakan ciri dari kedewasaan orang terpelajar. 
Menurut Haris Mujiman (2007: 1) "Kemandirian Belajar dapat diartikan sebagai sifat serta kemampuan yang dimiliki siswa untuk melakukan kegiatan belajar aktif, yang didorong oleh motif untuk menguasai sesuatu kompetensi yang telah dimiliki”. Penetapan kompetensi sebagai tujuan belajar, dan cara pencapaiannya baik penetapan waktu belajar, tempat belajar, irama belajar, tempo belajar, cara belajar, sumber belajar, maupun evaluasi hasil belajar dilakukan sendiri oleh siswa. Menurut Umar Tirtaraharja dan La Sulo (2005: 50) Kemandirian Belajar diartikan sebagai aktivitas belajar yang berlangsungnya lebih didorong oleh kemauan sendiri, pilihan sendiri, dan disertai rasa tanggung jawab dari diri pembelajar. Menurut Abu Ahmadi (2004: 31), "Kemandirian Belajar adalah sebagai belajar mandiri, tidak menggantungkan diri pada orang lain”. Siswa dituntut memiliki inisiatif, keaktifan dan keterlibatan dalam proses pembelajaran untuk meningkatkan Prestasi Belajar Akuntansi. Siswa dikatakan telah mampu belajar secara mandiri apabila telah mampu melakukan tugas belajar tanpa ketergantungan dengan orang lain. Pada dasarnya kemandirian merupakan perilaku individu yang mampu berinisiatif, mampu mengatasi hambatan/masalah, mempunyai rasa percaya diri dan tidak memerlukan pengarahan dari orang lain untuk melakukan kegiatan belajar. Menurut pengertian tersebut, dapat disimpulkan bahwa kemandirian belajar adalah suatu aktivitas/kegiatan belajar yang dilakukan oleh siswa atas kemauannya sendiri dan mempunyai rasa percaya diri tinggi dalam menyelesaikan tugasnya.

\section{c. Tinjauan tentang Lingkungan Belajar Siswa}

\section{1) Pengertian Lingkungan Belajar}

Lingkungan merupakan salah satu faktor yang mempengaruhi perkembangan manusia. Sartain (seorang ahli psikologi Amerika) dalam Ngalim Purwanto (2006: 28) mengatakan bahwa: "Lingkungan ialah meliputi semua kondisi-kondisi dalam dunia ini yang dalam cara-cara tertentu mempengaruhi tingkah laku, pertumbuhan, perkembangan atau life processes kecuali gen-gen dan bahkan gen-gen dapat pula dipandang sebagai menyiapkan lingkungan (to provide environment) bagi gen lain".

Menurut M. Dalyono (2005: 129) lingkungan itu sebenarnya mencakup segala material dan stimulus di dalam dan di luar individu baik yang bersifat fisiologis, psikologis, maupun bersifat sosio-kultural. Lingkungan juga didefinisikan oleh Patty yang dikutip oleh 
Baharuddin (2007: 68), "Lingkungan merupakan sesuatu yang mengelilingi individu di dalam hidupnya, baik dalam bentuk lingkungan fisik seperti orang tua, rumah, kawan bermain, dan masyarakat sekitar maupun dalam bentuk lingkungan psikologis seperti perasaan-perasaan yang dialami, cita-cita, persoalan-persoalan yang dihadapi dan sebagainya.

Dari definisi di atas dapat disimpulkan bahwa lingkungan belajar adalah sesuatu yang ada di sekitar tempat belajar siswa berpengaruh terhadap tingkah laku dan perkembangan dalam belajar baik secara langsung maupun tidak langsung.

\section{B. Metode Penelitian}

\section{Desain Penelitian}

Penelitian ini merupakan penelitian kausal-komparatif yang bersifat ex post facto yaitu penelitian yang dilakukan untuk menyelidiki kemungkinan hubungan sebab akibat yang berdasar atas pengamatan terhadap akibat yang ada mencari kembali faktor yang mungkin menjadi penyebab melalui data tertentu (Sumadi Suryabrata, 2011: 84). Pendekatan yang digunakan dalam penelitian ini adalah pendekatan kuantitatif karena data yang didapat berhubungan dengan angka yang memungkinkan digunakan teknik analisis statistik.

\section{Populasi Penelitian dan Sampel Penelitian}

\section{a. Populasi Penelitian}

Tabel 1. Jumlah populasi penelitian

\begin{tabular}{|c|c|}
\hline Kelas & Jumlah Siswa \\
\hline XI IPS 1 & 31 \\
\hline XI IPS 2 & 30 \\
\hline XI IPS 3 & 29 \\
\hline XI IPS 4 & 31 \\
\hline Jumlah siswa & 121 \\
\hline
\end{tabular}




\section{b. Sampel Penelitian}

Cara yang digunakan untuk pengambilan sampel secara random dalam penelitian ini dengan cara undian. Cara ini dilakukan sebagaimana jika mengadakan undian yaitu:

1. Membuat daftar yang berisi semua subjek/individu

2. Memberi kode nomor urut kepada semua subjek/individu

3. Menulis kode-kode tersebut masing-masing dalam selembar kertas kecil

4. Menggulung kertas-kertas dengan baik

5. Memasukkan gulungan kertas-kertas tersebut ke dalam tempolong (wadah)

6. Mengocok tempolong tersebut

7. Mengambil kertas-kertas gulungan itu satu demi satu sampai jumlah yang diperlukan tercapai (Cholid Narbuko dan Abu Achmadi, 2007: 111)

Dari populasi sebanyak 121 siswa, jumlah sampel yang diperlukan $0,70 \times 121=85$ siswa. Diperoleh angka 0,70 yaitu membuat garis dalam Nomogram Harry King dimulai pada titik populasi sebesar 121 dengan melewati taraf kesalahan 5\% maka akan ditemukan titik prosentase populasi yang diambil sebagai sampel sebesar $70 \%$ atau 0,70 . Perincian jumlah sampel dari siswa kelas XI IPS SMA Negeri 1 Sewon Bantul Tahun Ajaran 2010/2011 dapat dilihat sebagai berikut:

Tabel 2. Rincian Jumlah Sampel

\begin{tabular}{|c|c|c|c|}
\hline \multirow{2}{*}{ No. } & \multirow{2}{*}{ Kelas } & \multicolumn{2}{|c|}{ Jumlah } \\
\cline { 3 - 4 } & XI IPS 1 & 31 & $\frac{31}{121} \times 85=22$ \\
\hline 1. & & 30 & $\frac{30}{121} \times 85=21$ \\
\hline 2. & XI IPS 2 & 29 & $\frac{29}{121} \times 85=20$ \\
\hline 3. & XI IPS 3 & 31 & $\frac{31}{121} \times 85=22$ \\
\hline 4. & XI IPS 4 & & 85 \\
\hline \multicolumn{3}{|c|}{ Total } & \\
\hline
\end{tabular}




\section{Teknik Pengumpulan Data}

Teknik pengumpulan data merupakan cara yang digunakan untuk mengumpulkan data yang diperlukan. Adapun teknik pengumpulan data yang digunakan dalam penelitian ini adalah:

a. Angket

Angket digunakan untuk mengetahui data Kemandirian Belajar dan Lingkungan Belajar Siswa.

b. Dokumentasi

Teknik dokumentasi ini digunakan untuk mengetahui Prestasi Belajar Akuntansi Siswa Kelas XI IPS SMA Negeri 1 Sewon Tahun Ajaran 2010/2011 yang telah menempuh mata pelajaran Akuntansi dengan melihat nilai ulangan harian, nilai tugas dan nilai ujian tengah semester pada semester genap tahun ajaran 2010/2011. Nilai ini diperoleh dengan melihat nilai yang dimiliki guru.

\section{Teknik Analisis Data}

a. Uji Prasyarat Analisis

1) Uji Linearitas

2) Uji Multikolinieritas

3) Uji Normalitas

b. Uji Hipotesis

1) Analisis Regresi Sederhana

a) Membuat persamaan garis regresi linier sederhana

b) Menguji signifikansi dengan uji t

c) Mencari koefisien korelasi sederhana antara $X_{1}$ dan $X_{2}$ dengan $Y$

d) Mencari koefisien determinasi $\left(\mathrm{r}^{2}\right)$ antara prediktor $\mathrm{X}^{1}$ dan $\mathrm{X}^{2}$ dengan $\mathrm{Y}$

2) Analisis Regresi Ganda

a) Membuat persamaan garis dengan 2 prediktor dengan rumus

b) Mencari koefisien korelasi antara variabel $X_{1}$ dan $X_{2}$ dengan $Y$

c) Menguji keberartian regresi ganda dengan uji $\mathrm{F}$ 
d) Mencari Sumbangan Relatif

e) Mencari Sumbangan Efektif

\section{Hasil Penelitian dan Pembahasan}

\section{Pengaruh Kemandirian Belajar terhadap Prestasi Belajar Akuntansi}

Hasil penelitian ini menunjukkan bahwa terdapat pengaruh positif dan signifikan Kemandirian Belajar terhadap Prestasi belajar Akuntansi. Dari hasil analisis menggunakan regresi sederhana diperoleh harga koefisien $\left(\mathrm{X}_{1}\right)$ sebesar 0,510 dan bilangan konstantanya 47,622 persamaan garis regresinya adalah $Y=0,510+47,622$. Persamaan tersebut memiliki arti jika Kemandirian Belajar naik 1 satuan maka prestasi Belajar akan naik 0,510. Hasil pengujian menunjukkan harga koefisien korelasi 0,359 dan harga koefisien determinasi sebesar 0,129. Setelah dilakukan uji $t$ diperoleh $t_{\text {hitung }}$ sebesar dan $t_{\text {tabel }}$ pada taraf signifikansi $5 \%$ dengan $\mathrm{db}=$ sebesar 83. Harga $\mathrm{r}_{\mathrm{x} 1 \mathrm{y}}$ dan harga $\mathrm{r}_{\mathrm{x} 1 \mathrm{y}}^{2}$ menunjukkan $\mathrm{X}_{1}$ berpengaruh positif terhadap $\mathrm{Y}$ dan $\mathrm{t}_{\text {hitung }}$ lebih besar dari tabel menunjukkan pengaruh $\mathrm{X}_{1}$ terhadap $\mathrm{Y}$ adalah signifikan. Berdasarkan hal tersebut dapat disimpulkan terdapat pengaruh positif dan signifikan Kemandirian Belajar terhadap Prestasi Belajar Akuntansi Siswa kelas XI IPS SMA Negeri 1 Sewon Bantul Tahun Ajaran 2010/2011. Dengan demikian dapat dikatakan bahwa kemandirin Belajar berpengaruh terhadap Prestasi Belajar Akuntansi, semakin mendukung Kemandirian Belajar akan semakin tinggi pula Prestasi Belajar Akuntansi yang dicapai siswa, dan sebaliknya jika Kemandirian Belajar siswa kurang mendukung maka Prestasi Belajar Akuntansi Siswa akan semakin rendah pula.

Hasil penelitian ini didukung oleh teori dan penelitian yang relevan. Berdasarkan penelitian Umar Tirtaraharja dan La Sulo (2005: 50) kemandirian Belajar diartikan sebagai aktivitas belajar yang berlangsungnya lebih didorong oleh kemauan sendiri, pilihan sendiri, dan disertai rasa tanggung jawab dari diri pembelajar. Siswa memiliki Kemandirian Belajar yang tinggi akan mampu membuat keputusan dalam proses belajarnya sehingga dapat mempertanggungjawabkan keputusan yang diambil untuk mencapai prestasi belajarnya. Penelitian ini juga didukung oleh penelitian sebelumnya yang telah dilakukan Kurniasari (2010) yang menyimpulkan bahwa terdapat pengaruh positif dan signifikan kemandirian 
Belajar terhadap Prestasi Belajar Akuntansi Siswa Kelas XI IPS SMA N 2 Bantul Tahun Ajaran 2009/2010 ditunjukkan dengan $\mathrm{r}_{\mathrm{x} 2 \mathrm{y}}$ sebesar 0,417, harga r2x2y sebesar 0,174 dan hasil $t_{\text {hitung }} 5,383>t_{\text {tabel }}$ 1,655. Penelitian lain yang meneliti pengaruh Kemandirian Belajar terhadap prestasi Belajar Akuntansi adalah penelitian Anita Budhi Setyo tahun 2008 yang dilakukan pada siswa kelas II SMK Gajah Mungkur 2 Kabupaten Wonogiri Tahun Ajaran 2007/2008. Hasil penelitian menyatakan terdaparaft pengaruh positif dan signifikan Kemandirian Belajar terhadap Prestasi Belajar Akuntansi ditunjukkan dengan $r_{x 2 y}$ sebesar $0,729, r^{2} \times 2 y$ sebesar 0,531 , dan $t_{\text {thitung }} 7,136>t_{\text {tabel }} 2,000$ pada taraf signifikansi $5 \%$. Dengan demikian hasil penelitian tersebut memperkuat hasil penelitian ini yaitu trdapat pengaruh positif dan signifikan Kemandirian Belajar terhadap Prestasi Belajar Akuntansi Siswa Kelas XI IPS SMA negeri 1 Sewon Bantul Tahun Ajaran 2010/2011.

\section{Pengaruh Lingkungan Belajar Siswa terhadap Prestasi Belajar Akuntansi}

Hasil penelitian ini menunjukkan bahwa terdapat pengaruh positif dan signifikan Lingkungan Belajar Siswa terhadap Prestasi belajar Akuntansi. Dari hasil analisis menggunakan regresi sederhana diperoleh harga koefisien $\left(\mathrm{X}_{2}\right)$ sebesar 0,424 dan bilangan konstantanya 53,103 persamaan garis regresinya adalah $\mathrm{Y}=0,424+53,103$. Persamaan tersebut memiliki arti jika Lingkungan Belajar Siswa naik 1 satuan maka prestasi Belajar akan naik 0,424. Hasil pengujian menunjukkan harga koefisien korelasi 0,377 dan harga koefisien determinasi sebesar 0,142. Setelah dilakukan uji t diperoleh thitung sebesar dan ttabel pada taraf signifikansi $5 \%$ dengan $\mathrm{db}=83$ sebesar 1,980 . Harga $\mathrm{r}_{\mathrm{x} 2 \mathrm{y}} 0,377$ dan harga $\mathrm{r}^{2}$ x2y sebesar 0,142 menunjukkan $\mathrm{X}_{2}$ berpengaruh positif terhadap $\mathrm{Y}$ dan thitung 3,711 lebih besar dari tabel 1,980 menunjukkan pengaruh $\mathrm{X}^{2}$ terhadap $\mathrm{Y}$ adalah signifikan. Berdasarkan hal tersebut dapat disimpulkan terdapat pengaruh positif dan signifikan Lingkungan Belajar Siswa terhadap Prestasi Belajar Akuntansi Siswa kelas XI IPS SMA Negeri 1 Sewon Bantul Tahun Ajaran 2010/2011. Dengan demikian dapat dikatakan bahwa Lingkungan Belajar Siswa berpengaruh terhadap Prestasi Belajar Akuntansi, semakin mendukung Lingkungan Belajar Siswa akan semakin tinggi pula Prestasi Belajar Akuntansi yang dicapai siswa, dan 
sebaliknya jika Lingkungan Belajar Siswa kurang mendukung maka Prestasi Belajar Akuntansi Siswa akan semakin rendah pula.

Hasil penelitian ini didukung oleh teori Patty yang dikutip oleh Baharuddin (2007: 68), "Lingkungan merupakan sesuatu yang mengelilingi individu di dalam hidupnya, baik dalam bentuk lingkungan fisik seperti orang tua, rumah, kawan bermain, dan masyarakat sekitar maupun dalam bentuk lingkungan psikologis seperti perasaan-perasaan yang dialami, cita-cita, persoalan-persoalan yang dihadapi dan sebagainya. Lingkungan Belajar Siswa yang mendukung tentunya akan membangkitkan semangat belajar anak. Dengan demikian apabila Lingkungan Belajar Siswa mendukung maka akan berpengaruh positif terhadap Prestasi Belajar Akuntansi yang dicapai oleh siswa. Penelitian ini juga didukung oleh penelitian sebelumnya yang telah dilakukan Riya Ariyanti (2010) yang menyimpulkan bahwa terdapat pengaruh positif dan signifikan Lingkungan Belajar terhadap Prestasi Belajar Akuntansi Siswa Kelas X SMK Muhammadiyah 1 Wates Tahun Ajaran 2009/2010 ditunjukkan dengan $r_{x 1 y}$ sebesar 0,469, harga $r^{2}{ }_{x 1 y}$ sebesar 0,220 dan hasil thitung 5,060 $>t_{\text {tabel }} 1,980$. Penelitian lain yang meneliti pengaruh Lingkungan Belajar terhadap prestasi Belajar Akuntansi adalah penelitian dari Maharani Divi Basmar (2010). Hasil penelitian menyatakan terdapat pengaruh positif dan signifikan Lingkungan Belajar terhadap Prestasi Belajar Akuntansi ditunjukkan dengan dan $t_{\text {thitung }} 3,589>t_{\text {tabel }}$ 1,622 pada taraf signifikansi 5\%. Dengan demikian hasil penelitian tersebut memperkuat hasil penelitian ini yaitu terdapat pengaruh positif dan signifikan Lingkungan Belajar terhadap Prestasi Belajar Akuntansi Pada Siswa Kelas XI IS SMA N 1 Kasihan Bantul Tahun Ajaran 2009/2010.

\section{Pengaruh Kemandirian Belajar dan Lingkungan Belajar Siswa secara bersama- sama terhadap Prestasi Belajar Akuntansi}

Hasil penelitian ini menunjukkan bahwa terdapat pengaruh positif dan signifikan Kemandirian Belajar dan Lingkungan Belajar Siswa secara bersama-sama terhadap Prestasi Belajar Akuntansi. Dari hasil analisis menggunakan regresi ganda diperoleh harga koefisien $\mathrm{X}_{1}$ sebesar 0,456, koefisien $\mathrm{X}_{2}$ sebesar 0,384 dan konstanta $(\mathrm{k})$ sebesar 29,037 maka persamaan garis regresinya $\mathrm{Y}=0,456 \mathrm{X}_{1}+0,384 \mathrm{X}_{2}+29,037$. Persamaan tersebut 
menunjukkan bahwa nilai koefisien $\mathrm{X}_{1}$ sebesar 0,456, artinya apabila Kemandirian Belajar $\left(\mathrm{X}_{1}\right)$ meningkat 1 point maka nilai Prestasi Belajar Akuntansi (Y) akan meningkat 0,456 point, dengan asumsi $\mathrm{X}_{2}$ tetap dan apabila koefisien $\mathrm{X}_{2}$ meningkat 1 point maka pertambahan nilai pada Prestasi Belajar Akuntansi (Y) sebesar 0,384 dengan asumsi nilai $\mathrm{X}_{1}$ tetap. Dari hasil analisis juga diperoleh harga koefisien korelasi $\left(\mathrm{R}_{\mathrm{y}(1,2))}\right.$ sebesar 0,494 dan harga koefisien determinasi $\left(\mathrm{R}_{\mathrm{y}(1,2)}^{2}\right)$ sebesar 0,244. Setelah dilakukan uji F diperoleh $\mathrm{F}_{\text {hitung }}$ sebesar 13,264 dan $F_{\text {tabel }}$ pada taraf signifikansi 5\% dengan db 2:82 sebesar 3,11. Nilai $R_{y(1,2)}$ dan $\mathrm{R}^{2}{ }_{\mathrm{y}(1,2)}$ menunjukkan $\mathrm{X}_{1}$ dan $\mathrm{X}_{2}$ secara bersama-sama terhadap $\mathrm{Y}$ signifikan, sehingga dapat disimpulkan bahwa terdapat pengaruh positif dan signifikan Kemandirian Belajar dan Lingkungan Belajar Siswa Kelas XI IPS SMA Negeri 1 Sewon Bantul Tahun Ajaran 2010/2011. Dengan demikian Kemandirian Belajar yang tinggi dan Lingkungan Belajar Siswa yang mendukung secara bersama-sama akan meningkatkan kemauan dan semangat belajar siswa untuk mencapai Prestasi Belajar Akuntansi yang lebih optimal, sehingga dapat dikatakan bahwa semakin tinggi Kemandirian Belajar yang dimiliki siswa dan semakin mendukung Lingkungan Belajar Siswa maka akan semakin tinggi pula Prestasi belajar Akuntansi, dan sebaliknya jika Kemandirian Belajar kurang rendah maka Prestasi Belajar Akuntansi akan semakin rendah pula.

Hasil penelitian ini didukung oleh teori Ngalim Purwanto (2006: 102) yang menyebutkan bahwa prestasi belajar dipengaruhi oleh faktor individual dan faktor dari luar individu. Kemandirian Belajar merupakan faktor individual, sedangkan Lingkungan Belajar Siswa merupakan faktor luar individu yang dapat mempengaruhi prestasi belajar. Siswa yang lah Siswa yang tenang, nyaman, dan dapat belajar dengan lancar maka akan membantu siswa dalam memperoleh Prestasi belajar Akuntansi yang tinggi.

\section{Penutup}

\section{Kesimpulan}

Berdasarkan data yang diperoleh dari hasil analisis, maka kesimpulan yang dapat dikemukakan dalam penelitian ini adalah sebagai berikut: 
1. Terdapat pengaruh positif dan signifikan Kemandirian Belajar terhadap Prestasi Belajar Akuntansi Siswa Kelas XI IPS SMA Negeri 1 Sewon Bantul Tahun Ajaran 2010/2011. Hal ini ditunjukkan dengan harga koefisien korelasi $\left(r_{x 1 y}\right)$ sebesar 0,359 harga koefisien determinasi $\left(\mathrm{r}^{2}{ }_{\mathrm{x} 1 \mathrm{y}}\right)$ sebesar 0,129 dan harga $\mathrm{t}_{\text {hitung }}$ 3,509 lebih besar dari tabel 1,980. Hal ini ditunjukkan dengan sig $(p)$ 0,000 berarti lebih kecil dari 0,05. Persamaan garis regresinya $\mathrm{Y}=0,510 \mathrm{X}_{1}+47,622$. Dengan demikian apabila Kemandirian belajar $\left(\mathrm{X}_{1}\right)$ naik 1 satuan maka Prestasi belajar Akuntansinya akan naik sebesar 0,510.

2. Terdapat pengaruh positif dan signifikan Lingkungan Belajar Siswa terhadap Prestasi Belajar Akuntansi Siswa Kelas XI IPS SMA Negeri 1 Sewon Bantul Tahun Ajaran 2010/2011. Hal ini ditunjukkan dengan harga koefisien korelasi $\left(r_{x 2 y}\right)$ sebesar 0,377

harga koefisien determinasi $\left(\mathrm{r}^{2}{ }_{\mathrm{x} 2 \mathrm{y}}\right)$ sebesar 0,142 dan harga $\mathrm{t}_{\text {hitung }} 3,711$ lebih besar dari $t_{\text {tabel }}$ 1,980. Hal ini ditunjukkan dengan sig $(p)$ 0,000 berarti lebih kecil dari 0,05. Persamaan garis regresinya $\mathrm{Y}=0,424 \mathrm{X}_{2}+53,103$. Dengan demikian apabila Kemandirian belajar $\left(\mathrm{X}_{2}\right)$ naik 1 satuan maka Prestasi belajar Akuntansinya akan naik sebesar 0,424

3. Terdapat pengaruh positif dan signifikan Kemandirian Belajar dan Lingkungan Belajar Siswa secara bersama-sama terhadap Prestasi Belajar Akuntansi Siswa Kelas XI IPS SMA Negeri 1 Sewon Bantul Tahun Ajaran 2010/2011. Hal ini ditunjukkan dengan harga koefisien korelasi $\left(\mathrm{R}_{\mathrm{y}(1,2)}\right)$ sebesar 0,494 koefisien determinasi $\left(\mathrm{R}_{\mathrm{y}(1,2)}^{2}\right)$ sebesar 0,244 , dan harga $F_{\text {hitung }} 13,264$ lebih besar dari $F_{\text {tabel }}$ 3,11. Hal ini ditunjukkan dengan sig $(p)$ 0,003 berarti lebih kecil dari 0,05 . Persamaan garis regresinya $\mathrm{Y}==0,456 \mathrm{X}_{1}+0,384 \mathrm{X}_{2}+$ 29,037. Persamaan tersebut menunjukkan bahwa apabila nilai Kemandirian Belajar $\left(\mathrm{X}_{1}\right)$ meningkat 1 satuan maka nilai Prestasi Belajar Akuntansi (Y) akan meningkat sebesar 0,456 dengan asumsi $\mathrm{X}_{2}$ tetap dan apabila koefisien $\mathrm{X}_{2}$ meningkat 1 satuan maka pertambahan nilai pada Prestasi Belajar Akuntansi (Y) sebesar 0,384 dengan asumsi nilai $\mathrm{X}_{1}$ tetap. Kemandirian Belajar memberikan Sumbangan Relatif sebesar 55\% dan kemandirian Belajar memberikan Sumbangan Relatif sebesar 45\%, sedangkan Sumbangan Efektif masing-masing variabel adalah 13,45\% untuk variabel Kemandirian 
Belajar dan 10,95\% untuk variabel Lingkungan Belajar. Secara bersama-sama variabel Kemandirian Belajar dan Lingkungan Belajar Siswa memberikan sumbangan efektif sebesar 24,40\% terhadap pencapaian Prestasi Belajar Akuntansi.

\section{Saran}

Berdasarkan hasil pembahasan penelitian dan kesimpulan di atas maka dapat diberikan saran-saran sebagai berikut:

1. Bagi siswa, berdasarkan hasil penelitian ditemukan bahwa terdapat pengaruh positif dan signifikan Kemandirian Belajar Akuntansi. Oleh karena itu untuk meningkatkan Prestasi Belajar Akuntansi, siswa sebaiknya memiliki inisistif untuk mempelajari materi-materi Akuntansi sebelum guru mengajarkannya di kelas, selain itu siswa juga harus berusaha untuk memecahkan kesulitan-kesulitan dalam belajar Akuntansi. Berdasarkan hasil penelitian diketahui bahwa terdapat pengaruh positif dan signifikan Lingkungan Belajar Siswa terhadap Prestasi Belajar Akuntansi. Untuk itu dalam meningkatkan Prestasi Belajar Akuntansi, siswa perlu mengkondisikan agar Lingkungan Belajar Siswa yang tenang, apabila kondisi tidak memungkinkan siswa sebaiknya mengubah pola belajarnya di pagi hari saat suasana rumah dalam keadaan tenang agar dapat berkonsentrasi dengan baik.

2. Bagi sekolah dan guru, supaya Prestasi Belajar Akuntansi bisa meningkat dan untuk meningkatkan Kemandirian Belajar, guru perlu memberikan tugas-tugas mandiri agar siswa mau berusaha untuk mempelajari materi Akuntansi tidak hanya dari buku paket yang diwajibkan saja, pihak sekolah juga perlu menerapkan peraturan dan sanksi yang tegas untuk siswa apabila ada siswa yang mencontek, sedangkan untuk meningkatkan Lingkungan Belajar Siswa di sekolah, sekolah diharapkan dapat membenahi Lingkungan Belajar Siswa di sekolah dan memberikan saran kepada orang tua siswa agar memantau kegiatan belajar anak di rumah. Pihak sekolah perlu mengkondisikan fasilitas-fasilitas sekolah seperti perpustakaan dan laboratorium akuntansi agar nyaman di pakai siswa misalnya dengan cara memberikan penerangan yang cukup untuk ruang perpustakaan agar siswa dapat membaca dengan jelas. 
3. Bagi peneliti lain, dalam penelitian ini membahas tentang Prestasi Belajar Akuntansi yang melibatkan dua variabel yaitu Kemandirian Belajar dan Lingkungan Belajar Siswa. Namun di luar itu masih banyak variabel lain yang berpengaruh seperti bakat, minat, kedisiplinan, kebiasaan belajar, dan sebagainya. Oleh karena itu dimungkinkan bagi peneliti lain untuk melakukan penelitian tentang variabel-variabel lain yang berkaitan dengan Prestasi Belajar Akuntansi

\section{E. Daftar Pustaka}

Abu Ahmadi. (2004). Teknik Belajar yang Efektif. Jakarta: PT. Rineka Cipta

Anita Budi Setyo Mardhiyani. (2008). Pengaruh Motivasi Berprestasi dan Kemandirian Belajar Terhadap Prestasi Belajar Akuntansi Pada Siswa Kelas II SMK Gajah Mungkur 2 Giritontro Kabupaten Wonogiri Tahun Ajaran 2008/2009. Skripsi. Yogyakarta: FISE UNY

Baharuddin. (2007). Psikologi Pendidikan. Yogyakarta: Ar Ruzz Media

Bimo Walgito. (2004). Pengantar Psikologi Umum. Yogyakarta: Andi Offset

Cholid N dan Abu Achmadi. (2007). Metodologi Penelitian. Jakarta: Bumi Aksara

Dalyono. (2005). Psikologi Pendidikan. Jakarta: Rineka Cipta

Djemari Mardapi. (2008). Teknik Penyusunan Tes Dan Nontes. Yogyakarta: Mitra Cendekia Haris Mujiman. (2007). Manajemen Pelatihan Berbasis Belajar Mandiri. Yogyakarta: Mitra Cendekia

Hendi Somantri. (2007). Memahami Siklus Akuntansi Perusahaan Jasa Dan Dagang. Bandung: Armico

Ismani, dkk. (2010). Pedoman Penulisan Tugas Akhir. Yogyakarta: Jurusan Pendidikan Akuntansi UNY

Kurniasari. (2010). Pengaruh Motivasi Berprestasi dan Kemandirian Belajar Terhadap Prestasi Belajar Akuntansi Siswa Kelas XI IPS SMA Negeri 2 Bantul Tahun Ajaran 2009/2010. Skripsi. Yogyakarta: FISE UNY

Maharani Divi Basmar. (2010). Pengaruh Lingkungan Belajar dan Motivasi Belajar Terhadap Prestasi Belajar Akuntansi Pada Siswa Kelas XI IS SMA N 1 Kasihan Bantul Tahun Ajaran 2009/2010. Skripsi. Yogyakarta: FISE UNY 
Mohammad Ali dan Mohammad Asrori. (2005). Psikologi Remaja. Jakarta: Bumi Aksara Muhibbin Syah. (2008). Psikologi Pendidikan dengan Pendekatan Baru. Jakarta: PT Remaja Rosdakarya

Nana Syaodih Sukmadinata. (2005). Landasan Psikologi Proses Pendidikan. Bandung: PT. Remaja Rosdakarya

Ngalim Purwanto. (2006). Psikologi Pendidikan. Bandung: PT Remaja Rosdakarya

Natalia Siwi Satmawati. (2010). Pengaruh Disiplin Belajar dan Lingkungan Belajar Terhadap Prestasi Belajar Akuntansi Pada Siswa Kelas X program Keahlian Akuntansi SMK N 1 Bantul Tahun Ajaran 2009?2010. Skripsi. Yogyakarta: FISE UNY

Paul Suparno, dkk. (2003). Pendidikan Budi Pekerti. Yogyakarta: Kanisius

Riya Ariyanti. (2010). Pengaruh Lingkungan Belajar dan Gaya Belajar Siswa Terhadap Prestasi Belajar Akuntansi Siswa Kelas X Program Keahlian Akuntansi Di SMK Muhammadiyah 1 Wates Kulon Progo Tahun Ajaran 2009/2010. Skripsi. Yogyakarta: FISE UNY

Saefuddin Azwar. (2011). Penyusunan Skala Psikologi. Yogyakarta: MA Pustaka Pelajar

Slameto. (2010). Belajar dan Faktor-faktor yang Mempengaruhinya. Jakarta: PT Rineka Cipta

Sugiyono. (2009). Metodologi Penelitian Pendidikan Pendekatan Kuantitatif, Kualitatif, dan $R \& D$. Bandung: Alfabeta . (2005). Statistika untuk Penelitian. Bandung: Alfabeta

Suharsimi Arikunto. (2006). Prosedur Penelitian. Jakarta: Rineka Cipta (2007). Dasar-Dasar Evaluasi Pendidikan. Jakarta: Rineka Cipta

Sumadi Suryabrata. (2004). Psikologi Pendidikan. Jakarta: PT Raja Grafindo Persada . (2011). Metodologi Penelitian. Jakarta: PT Raja Grafindo Persada

Sutrisno Hadi. (2004). Analisis Regresi. Yogyakarta: Andi Offset

Umar dan La Sulo. (2005). Pengantar Pendidikan. Jakarta: PT Rineka Cipta. 